\title{
A Comparison of Pearl Millet and Sorghum-Sudangrass Pastures during the Frost-Prone Autumn for Growing Beef Cattle in Semiarid Region
}

\author{
Leonard M. Lauriault ${ }^{1, *}$, Leah H. Schmitz ${ }^{2,+}$, Shad H. Cox ${ }^{3}$ and Eric J. Scholljegerdes ${ }^{2}$ \\ 1 Rex E. Kirksey Agricultural Science Center, New Mexico State University, Tucumcari, NM 88401, USA \\ 2 Department of Animal and Range Sciences, New Mexico State University, Las Cruces, NM 88003, USA; \\ leahlack77@gmail.com (L.H.S.); ejs@nmsu.edu (E.J.S.) \\ 3 Corona Range and Livestock Research Center, New Mexico State University, Corona, NM 88318, USA; \\ shadcox@nmsu.edu \\ * Correspondence: lmlaur@nmsu.edu \\ † Current address: 3-V Dairy, Roswell, NM 88203, USA.
}

check for updates

Citation: Lauriault, L.M.; Schmitz, L.H.; Cox, S.H.; Scholljegerdes, E.J. A Comparison of Pearl Millet and Sorghum-Sudangrass Pastures during the Frost-Prone Autumn for Growing Beef Cattle in Semiarid Region. Agriculture 2021, 11, 541. https://doi.org/10.3390/ agriculture11060541

Academic Editor: David Parsons

Received: 28 April 2021

Accepted: 10 June 2021

Published: 12 June 2021

Publisher's Note: MDPI stays neutral with regard to jurisdictional claims in published maps and institutional affiliations.

Copyright: (c) 2021 by the authors. Licensee MDPI, Basel, Switzerland. This article is an open access article distributed under the terms and conditions of the Creative Commons Attribution (CC BY) license (https:/ / creativecommons.org/licenses/by/ $4.0 /)$.

\begin{abstract}
Sorghum-sudangrass (Sorghum bicolor $\times$ S. sudanense (Piper) Stapf.) and pearl millet (Pennisetum glaucum (L.) R. Br.) provide adequate nutritive value for growing beef cattle; however, unlike pearl millet, sorghum-sudangrass produces hydrocyanic acid (which is toxic to livestock) when frosted. Forage yield, nutritive value, and weight gain of growing cattle grazing sorghumsudangrass and pearl millet were compared during the frost-prone autumns of 2013 and 2014, at New Mexico State University's Rex E. Kirksey Agricultural Science Center in Tucumcari, NM USA, in randomized complete block designs each year with two replicates. No differences existed between pearl millet and sorghum-sudangrass forage yield, although there was a year-forage interaction for fiber-based nutritive value components because of maturity differences across years between the forages when freeze-killed. Pearl millet allowed for extending grazing of available forage for an additional 14 and 24 d in 2013 and 2014, respectively, compared to sorghum-sudangrass during the frost-prone autumn periods. During that period, when sorghum forages produce potentially toxic levels of hydrocyanic acid, animals grazing pearl millet accumulated an additional average of $94.9 \mathrm{~kg}$ live-weight gain ha ${ }^{-1}(p<0.001)$. These factors afford producers an opportunity to increase returns on the similar investments of establishing and managing warm-season annual forage crops each year, and allow more time to stockpile cool-season perennial and annual forages for winter and early spring grazing, or to reduce hay feeding.
\end{abstract}

Keywords: animal performance; forage nutritive value; forage yield; growing beef cattle; hydrocyanic acid; pastures; pearl millet; sorghum-sudangrass

\section{Introduction}

Semiarid regions are characterized by limited and erratic precipitation, high summer temperatures, and low soil fertility [1,2], as well as early autumn freezes [3] that are not predictable at spring planting time. Warm-season annual grass forage crops, such as sorghum forages (forage sorghum, Sorghum bicolor (L.) Moench and sorghum-sudangrass S. bicolor $\times$ S. sudanense (Piper) Stapf.) and pearl millet (Pennisetum glaucum (L.) R. Br.) are grown for grain and forage, and are broadly adapted to semiarid climates, being droughttolerant and requiring low inputs to maximize productivity $[1,2,4]$. They can be significant summer-period components of year-round forage systems for high-performing livestock, such as growing beef cattle [5,6], providing adequate nutritive value [7].

Ward et al. [8] described sorghum-sudangrass and pearl millet as late-summer forage crops because they can be grown later than maize (Zea mays L.), and do not interfere with winter forage and grain crops for double cropping. Both species respond to applied water 
and fertilizer $[1,4,5]$, but forage production can still be influenced by the amount and distribution of precipitation [9]. The typical growth pattern of these two species can lead to an overabundance or shortage of forage at different times of the year [7]. To overcome this concern, Fontaneli et al. [5] recommended early and late plantings three to six weeks apart.

Hydrocyanic acid (HCN, also known as prussic acid) is formed in sorghum forages when the plants are stressed or frost-damaged $[4,6,10]$. The $\mathrm{HCN}$, which is toxic to ruminant livestock, generally dissipates in a matter of days to two weeks after the stress is relieved or no additional frost occurs, depending on plant height [10], at which time animals can be returned to the pasture. This being said, if there is any regrowth on partially killed plants after frost, this new growth can be toxic until it is $>45 \mathrm{~cm}$ tall [10]. Toxic levels of nitrates can also be present in shorter growth, whether from a new seeding, after regrowth, or after recovery from stress, including frost [6]. The recommendation is to not return livestock to frosted sorghum forages until two weeks after all plants are completely dead [10]. This necessitates the availability of alternative pasture throughout the frost-prone autumn period, which can begin as early as mid-September or delayed as late as mid-November in the semiarid Southern High Plains of the USA [3], thereby, adding production costs to the system. When available, cool-season annual and perennial forages can be used as alternative pastures; however, delaying grazing of those species allows them to accumulate greater forage for grazing during winter and early spring [11].

Rabas et al. [12] also reported that the concentration of HCN was negatively correlated with the grazing preference of both cattle and sheep. Pearl millet does not produce $\mathrm{HCN}[1,4,13]$ and can be used for grazing at any stage of the crop for that reason [13].

Much of the research comparing the productivity of sorghum and pearl millet forages has been conducted in humid, subtropical high-precipitation regions, including the extreme Southern USA. However, no studies have reported growing beef cattle weight gain when grazing sorghum-sudangrass or pearl millet during autumn when frosts and hard freezes become prevalent in the semiarid subtropical regions, such as the Southern High Plains of the USA [3]. The objectives of this study were to compare sorghum-sudangrass and pearl millet for season-long single-cut forage production and nutritive value, as well as the weight gain of growing beef cattle through the frost-prevalent autumn season.

\section{Materials and Methods}

\subsection{Test Description, Management, and Data Collection}

Studies were conducted in the Southern High Plains of the USA at the New Mexico State University Rex E. Kirksey Agricultural Science Center in Tucumcari, NM, USA $\left(35.20^{\circ} \mathrm{N}, 103.69^{\circ} \mathrm{W}\right.$; elev. $\left.1247 \mathrm{~m}\right)$, in a completely randomized design with two replicates per treatment in each of 2013 and 2014 to determine the relative effect of pearl millet and sorghum-sudangrass pastures (forage) on weight gain of growing cattle. Pastures were drilled with a $17.78 \mathrm{~cm}$ row spacing into conventionally tilled seedbeds on 28 June 2013 and 16 June 2014, and sprinkler-irrigated with treated municipal wastewater (class 1B). Class $1 \mathrm{~B}$ treatment is greater than that required for application of treated municipal wastewater to animal feed and fiber crops [14] Irrigations totaled 335 and $348 \mathrm{~mm}$ to supplement 199 and $169 \mathrm{~mm}$ precipitation throughout the pre-grazing and grazing periods of $2013(130 \mathrm{~d})$ and $2014(140 \mathrm{~d})$, respectively. The seeding rate was 40 and $22.5 \mathrm{~kg} \mathrm{ha}^{-1}$ for sorghumsudangrass and pearl millet, respectively. Metolachlor $\left(1.32 \mathrm{~L}\right.$ active ingredient ha $\left.{ }^{-1}\right)$ was applied each year, shortly after planting to the sorghum-sudangrass pastures only, and incorporated with irrigation. Fertilizer $\left(19.5 \mathrm{~kg} \mathrm{~N} \mathrm{ha}^{-1}\right.$ in 2013 and $29.2 \mathrm{~kg} \mathrm{~N}+21.3 \mathrm{~kg}$ $\mathrm{P}_{2} \mathrm{O}_{5} \mathrm{ha}^{-1}$ in 2014) were applied based on soil test recommendations approximately three weeks after seeding to supplement soil residual 73.6 and $10.0 \mathrm{~kg} \mathrm{~N}^{-1}$ in 2013 and 2014, respectively. On 23 July 2013, diglycolamine salt of 3,6-dichloro-o-anisic acid (0.33 L active ingredient $\mathrm{ha}^{-1}$ ) was applied to control emerged broadleaf weeds in all pastures.

Pastures were of the same size each year (approximately 1.82 ha each) and three $1.22 \mathrm{~m} \times 1.22 \mathrm{~m}$ exclosures were uniformly distributed in each pasture prior to grazing. Six weaned British $\times$ Continental crossbred beef heifers from the NMSU Corona Range 
and Livestock Research Center were assigned to each pasture replicate each year by initial live weight $(292.7 \pm 26.8 \mathrm{~kg}$ in 2013 and $331.8 \pm 41.8 \mathrm{~kg}$ in 2014) to have the same stocking density within the year. Continuous grazing was initiated on 13 August 2013, and 10 September 2014. Minerals (Hi-Pro Beef Range Mineral, Friona, TX, USA) were supplied ad libitum in each pasture.

Every 28 days, heifers were weighed after a $16 \mathrm{~h}$ fast with water, and standing forage in a measured area $(1.5 \mathrm{~m} \times$ measured length) was harvested near each of the three exclosures in each pasture leaving a $5 \mathrm{~cm}$ stubble using a self-propelled forage plot harvester equipped with a weighing system. Harvested areas in each pasture were selected to represent the average of the standing grazed forage surrounding the closest exclosure. A sub-sample of each harvested area was collected and dried in a forced-air oven at $60{ }^{\circ} \mathrm{C}$ for $48 \mathrm{~h}$ to determine dry matter (DM) percentage and yield.

Grazing of the sorghum-sudangrass pastures ended on 22 October 2013, and 11 November 2014, due to anticipated hard freeze or frost, which occurred that night or the next morning, and those animals were removed, held off feed for $16 \mathrm{~h}$ and weighed. Grazing ended on the pearl millet pastures on 5 November 2013, and 4 December 2014, which were the next scheduled weigh days each year and because it was anticipated that forage would soon become limiting. Season-long average daily gains (ADG) and total gain ha ${ }^{-1}$ were calculated for each pasture replicate using initial and final live weights.

After grazing of pearl millet pastures ended, standing forage within exclosures was harvested and subsampled as before to estimate single-cut hay production and nutritive value in the absence of grazing. As before, a sub-sample of each harvested area was collected and dried in a forced-air oven at $60{ }^{\circ} \mathrm{C}$ for $48 \mathrm{~h}$ to determine DM percentage and yield and these samples were held for subsequent nutritive value estimation by nearinfrared spectroscopy (NIRS) at Ward Laboratory (Kearney, NE, USA) using an equation developed for grass hay including annual warm-season grasses by the NIRS Consortium (https: / / www.nirsconsortium.org / ; accessed on 11 June 2021). Stand age of the single-cut forage was 130 and 140 days after planting (DAP) in 2013 and 2014, respectively.

\subsection{Statistical Analysis}

Each year was a completely randomized design with two replications. Forage and cattle data were averaged by pasture, as the experimental unit of which there were two replicates in each of the two years, and analyzed with the mixed procedure of SAS (SAS Inst., Cary, NC, USA) [15] to compare forage (sorghum-sudangrass or pearl millet), year, and their interaction. Year, rep $\times$ year, and residual mean squares were considered random and used as denominators for tests of significance [16]. All differences reported are significant at $p<0.05$. When the year-forage interaction was significant, least significant differences were used to determine where differences occurred among treatment least squares means using the PDMIX800 SAS macro (SAS Inst., Cary, NC, USA) [17].

\section{Results and Discussion}

\subsection{Single-Cut Forage Yield and Nutritive Value}

Single-cut forage yield and nutritive value data and results of statistical analyses across both years are presented in Table 1. There was no difference in single-cut hay yield between forages and no year-forage interaction. Rabas et al. [12] reported no difference among DM yield of varieties of sorghum-sudangrass and sudangrass.

Yields in the present study were generally consistent in rank, but slightly greater than those measured elsewhere. Otherwise, differences among studies is likely due to multiple factors, including stand age at harvest. Machicek et al. [2], near the location of the present study, reported 6.29 and $11.05 \mathrm{Mg} \mathrm{ha}^{-1}$ for a single harvest of pearl millet and sorghum-sudangrass, respectively, taken 90 DAP. Franzluebbers and Stuedemann [18] reported ungrazed pearl millet cover crop and sorghum post-grain harvest stover yields averaging 8.89 and $6.35 \mathrm{Mg} \mathrm{ha}^{-1}$ over 4 years, respectively, when planted in spring and harvested at or near the season's end. The sorghum grain yield in that study added another 
3.45 $\mathrm{Mg} \mathrm{ha}^{-1}$, for a total sorghum biomass production of $9.8 \mathrm{Mg} \mathrm{ha}^{-1}$. On the other hand, pearl millet cultivars produced more forage than sorghum-sudangrass cultivars in a study by Fontaneli et al. [5].

Table 1. Dry matter (DM) yield and nutritive value of freeze-killed pearl millet (PM) and sorghum-sudangrass (SS) from a single cutting at Tucumcari, NM, USA, in 2013 and 2014 (130 and 140 days after planting in 2013 and 2014, respectively). Data are the least squares means of two replicates and two years.

\begin{tabular}{|c|c|c|c|c|c|c|}
\hline Forage & $\begin{array}{c}\text { Yield } \\
\text { Mg DM ha }^{-1}\end{array}$ & $\mathrm{CP}^{1}$ & ADF & $\begin{array}{l}\text { NDF } \\
\mathrm{g} \mathrm{kg}^{-1}\end{array}$ & NDFD & IVTDMD \\
\hline PM & 9.15 & 68.5 & 379.8 & 685.0 & 563.5 & 720.3 \\
\hline SS & 11.56 & 61.4 & 338.3 & 580.3 & 628.5 & 782.5 \\
\hline SED & 1.56 & 10.0 & 7.2 & 11.2 & 2.1 & 0.1 \\
\hline & \multicolumn{6}{|c|}{$p$-values } \\
\hline Forage & 0.2637 & 0.5529 & $0.0286^{\prime}$ & 0.0057 & 0.0011 & 0.0082 \\
\hline Year $\times$ Forage & 0.8780 & 0.3254 & 0.0325 & 0.0134 & 0.0015 & 0.0117 \\
\hline
\end{tabular}

${ }^{1} \mathrm{CP}, \mathrm{ADF}, \mathrm{NDF}, \mathrm{NDFD}$, IVTDMD and SED signify crude protein, acid detergent fiber, neutral detergent fiber, NDF digestibility, in vitro true dry matter digestibility, and standard error of the difference between means, respectively.

There was also no difference between forages and no year-forage interaction for crude protein (CP) (Table 1). Fontaneli et al. [5] also reported no differences among sorghum-sudangrass and pearl millet cultivars for $\mathrm{CP}$ concentration. Crude protein in the present study was considerably lower than the $160 \mathrm{~g} \mathrm{~kg}^{-1}$ reported by Fontaneli et al. [5], but consistent with that of others they cited, who reported CP concentrations as low as $80 \mathrm{~g} \mathrm{~kg}^{-1}$ for late-harvested sorghum-sudangrass. Machicek et al. [2] reported an average $\mathrm{CP}$ of $47 \mathrm{~g} \mathrm{~kg}^{-1}$ for sorghum-sudangrass and pearl millet, taken $90 \mathrm{DAP}$, consistent with the present study. The consistencies between the present study and results reported by Machicek et al. [2] are probably related to multiple factors, including low $\mathrm{N}$ levels applied compared to other studies, but based on soil test recommendations, along with greater yields, later maturity at harvest, and regular application of irrigation, which can leach nitrogen. Fulkerson et al. [19] reported that CP of sorghum-sudangrass declined from 217 to $168 \mathrm{~g} \mathrm{~kg}^{-1}$ by autumn, which coincides with the grazing period of the present study. Redmon et al. [7] found that pearl millet CP declined as harvest was delayed from 30 to 50 DAP, and Parish et al. [20] reported declines in CP of sudangrass as time progressed from 42 to 98 DAP.

In the present study, differences between forages for all fiber-based variables and the year-forage interaction existed for acid detergent fiber (ADF), neutral detergent fiber (NDF), NDF digestibility (NDFD), and in vitro true dry matter digestibility (IVTDMD) (Tables 1 and 2).

Table 2. The influence of year and forage species on forage fiber and digestibility of freeze-killed pearl millet (PM) and sorghum-sudangrass (SS) from a single cutting at Tucumcari, NM USA in 2013 and 2014 (130 and 140 days after planting in 2013 and 2014, respectively). Data are the least squares means of two replicates.

\begin{tabular}{|c|c|c|c|c|c|c|c|c|c|}
\hline \multirow{3}{*}{$\begin{array}{c}\text { Variable } \\
\mathrm{ADF}, \mathrm{g} \mathrm{kg}^{-1}\end{array}$} & \multicolumn{4}{|c|}{2013} & \multicolumn{4}{|c|}{2014} & \multirow{3}{*}{$\begin{array}{r}\text { SED }^{1} \\
0.10\end{array}$} \\
\hline & \multicolumn{2}{|c|}{ PM } & \multicolumn{2}{|c|}{ SS } & \multicolumn{2}{|c|}{ PM } & \multicolumn{2}{|c|}{ SS } & \\
\hline & 341.5 & $\mathrm{~B}^{2}$ & 330.0 & B & 418.0 & A & 346.5 & B & \\
\hline $\mathrm{NDF}, \mathrm{g} \mathrm{kg}^{-1}$ & 618.5 & B & 565.5 & $\mathrm{C}$ & 751.5 & A & 595.0 & $\mathrm{BC}$ & 11.2 \\
\hline NDFD, $\mathrm{g} \mathrm{kg}^{-1}$ & 617.0 & B & 617.0 & B & 510.0 & $\mathrm{C}$ & 640.0 & $\mathrm{~A}$ & 3.0 \\
\hline IVTDMD, $\mathrm{g} \mathrm{kg}^{-1}$ & 772.0 & A & 790.0 & A & 668.5 & B & 775.0 & A & 8.0 \\
\hline
\end{tabular}

${ }^{1} \mathrm{SED}, \mathrm{ADF}, \mathrm{NDF}, \mathrm{NDFD}$, and IVTDMD, signify standard error of the difference between mean, acid detergent fiber, neutral detergent fiber, NDF digestibility, and in vitro true dry matter digestibility, respectively. ${ }^{2}$ Means within a row followed by the same letter are not significantly different at $p=0.05$. 
The year-forage interactions were due to pearl millet being generally more mature than sorghum-sudangrass when freeze-killed in 2014, leading to greater ADF and NDF, and lesser NDFD and IVTDMD (Table 2). The data still compare well with those reported elsewhere. Fulkerson et al. [19] reported an average summer ADF of 307 and $343 \mathrm{~g} \mathrm{~kg}^{-1}$ of pearl millet and sorghum-sudangrass, respectively, and an NDF of 501 and $509 \mathrm{~g} \mathrm{~kg}^{-1}$, respectively, in summer. There was little change in the ADF of sorghum-sudangrass, but the average autumn NDF had increased from the summer to $614 \mathrm{~g} \mathrm{~kg}^{-1}$ in the study by Fulkerson et al. [19]. Parish et al. [20] also reported declines in digestibility, coupled with increases in ADF and NDF, over 56 days of grazing sudangrass from about 42 to $98 \mathrm{DAP}$, and Redmon et al. [7] reported increases in the ADF and NDF of pearl millet over a 3-week period from about 30 to 50 DAP. Vendramini et al. [21] reported greater late-season digestibility for pearl millet than sorghum-sudangrass ( $645 \mathrm{vs.} 574 \mathrm{~g} \mathrm{~kg}^{-1}$ for digestibility of pearl millet and sorghum-sudangrass, respectively, in September). Machicek et al. [2] attributed the decline in nutritive value over time to a decrease in the leaf:stem ratio of both crops as they mature and senesce $[4,20]$.

\subsection{Pasture Availability and Animal Performance}

Initial and final forage availability and animal weight gain data are presented in Table 3.

Table 3. Pasture dry matter (DM) availability and animal weight gain of growing beef cattle grazing pearl millet (PM) and sorghum-sudangrass (SS) pastures during the frost-prone autumn at Tucumcari, NM USA, in 2013 and 2014. Data are the least squares means of two replicates and two years.

\begin{tabular}{|c|c|c|c|c|c|c|}
\hline \multirow{2}{*}{ Forage } & \multicolumn{2}{|c|}{ Pasture Availability } & \multirow{2}{*}{$\mathrm{ADG}^{1}$} & \multicolumn{3}{|c|}{ Live-Weight Gain } \\
\hline & Initial & Final & & Pre-Frost & Post-Frost & Total \\
\hline & \multicolumn{2}{|c|}{ Mg DM ha ${ }^{-1}$} & kg head ${ }^{-1}$ day $^{-1}$ & \multicolumn{3}{|c|}{$\mathrm{kg} \mathrm{ha}^{-1}$} \\
\hline PM & 6.63 & 1.65 & 0.91 & 170.9 & 94.9 & 265.8 \\
\hline SS & 7.59 & 3.87 & 0.84 & 197.6 & 0.0 & 197.6 \\
\hline SED $^{2}$ & 0.20 & 0.39 & 0.05 & 13.3 & 3.1 & 11.4 \\
\hline & & & $p$-values & & & \\
\hline Forage & 0.0423 & 0.0048 & 0.2561 & 0.1828 & 0.0010 & 0.0268 \\
\hline Year $\times$ Forage & 0.0128 & 0.0007 & 0.0110 & 0.1318 & 0.0954 & 0.0641 \\
\hline
\end{tabular}

${ }^{1}$ ADG (average daily gain on a per animal basis) was calculated based on total individual animal gain and the number of days on treatment, which was 84 and $70 \mathrm{~d}$ for pearl millet and sorghum-sudangrass, respectively, in 2013, and 86 and $62 \mathrm{~d}$ for pearl millet and sorghum-sudangrass, respectively, in 2014. ${ }^{2}$ SED signifies standard error of the difference between means, respectively.

The year-forage interaction was significant for both the initial and final forage availability, because both were greater for sorghum-sudangrass than pearl millet in 2014 (Table 4). Otherwise, the rate of subsequent growth and removal by the animals was consistent between forages across measurement periods, as indicated by a nonsignificant forage-harvest date interaction $(p<0.90$; data not shown, but note the consistency in the differences between initial and final pasture availability of 3.98 and $3.72 \mathrm{Mg} \mathrm{ha}^{-1}$ for pearl millet and sorghum-sudangrass, respectively, calculated from Table 3.). In 2013, the initiation of grazing took place about the time the first harvest of sorghum-sudangrass is normally taken at this location in a two-cut system (mid-August). The delivery of cattle was delayed in 2014, allowing for greater accumulation of forage before the onset of grazing (initial availability), and greater residual forage when grazing ended (final availability) (Table 4). Forage availability was never limiting and in 2014, sufficient standing forage was available after the grazing of both forages to warrant a single cutting of lower-quality forage (data not shown). 
Table 4. The influence of year and forage species on pasture dry matter (DM) availability and animal weight gain of growing beef cattle grazing pearl millet (PM) and sorghum-sudangrass (SS) pastures during the frost-prone autumn at Tucumcari, NM USA, in 2013 and 2014. Data are the least squares means of two replicates.

\begin{tabular}{|c|c|c|c|c|c|c|c|c|c|}
\hline \multirow{2}{*}{ Variable } & \multicolumn{4}{|c|}{2013} & \multicolumn{4}{|c|}{2014} & \multirow{2}{*}{ SED $^{1}$} \\
\hline & \multicolumn{2}{|c|}{ PM } & \multicolumn{2}{|c|}{ SS } & \multicolumn{2}{|c|}{ PM } & \multicolumn{2}{|c|}{ SS } & \\
\hline Initial availability, $\mathrm{Mg} \mathrm{DM} \mathrm{ha}^{-1}$ & 3.42 & $C^{2}$ & 3.73 & $\mathrm{C}$ & 9.84 & $\mathrm{~B}$ & 11.44 & $\mathrm{~A}$ & 0.29 \\
\hline Final availability, $\mathrm{Mg} \mathrm{DM} \mathrm{ha}^{-1}$ & 0.62 & $\mathrm{C}$ & 0.72 & $\mathrm{C}$ & 2.67 & $\mathrm{~B}$ & 7.01 & A & 0.55 \\
\hline Days of grazing & 84 & & 70 & & 86 & & 62 & & - \\
\hline $\mathrm{ADG}^{3}, \mathrm{~kg} \mathrm{hd}^{-1} \mathrm{~d}^{-1}$ & 1.12 & A & 0.83 & $\mathrm{~B}$ & 0.70 & $\mathrm{~B}$ & 0.85 & $\mathrm{~B}$ & 0.07 \\
\hline
\end{tabular}

${ }^{1}$ SED signifies standard error of the difference between means. ${ }^{2}$ Means within a row followed by the same letter are not significantly different at $p=0.05 .{ }^{3}$ ADG (average daily gain on a per animal basis) was calculated based on total individual animal gain and the number of days on treatment, which was 84 and $70 \mathrm{~d}$ for pearl millet and sorghum-sudangrass, respectively, in 2013, and 86 and $62 \mathrm{~d}$ for pearl millet and sorghum-sudangrass, respectively, in 2014.

There was no difference between forages for ADG (Table 3), but a significant yearforage interaction occurred because growing cattle grazing pearl millet had greater ADG in 2013 than in 2014, and than those grazing sorghum-sudangrass in both years (Table 4). While the ADG of sorghum-sudangrass was consistent across years, lesser ADG for pearl millet in 2014 than for pearl millet in 2013 is likely associated with the greater maturity of the pearl millet at the onset of grazing that year, and the resultant reduced forage IVTDMD throughout the grazing period (Table 2), but pearl millet ADG in 2014 was still equal to that of sorghum-sudangrass in both years (Table 4), despite the lesser digestibility (Table 2). Hence, cattle weight gain on pearl millet is greater when pearl millet and sorghum-sudangrass have equal nutritive value, but weight gain of cattle grazing pearl millet of lesser nutritive value can still equal that of sorghum-sudangrass. The extent to which this effect applies, in regard to greater or lesser nutritive value of pearl millet, was not evaluated in the present study. Vendramini et al. [21], during a predominantly frost-free late summer and autumn in the Southeastern USA (https://www.plantmaps. com/interactive-florida-first-frost-date-map.php; accessed on 11 June 2021), reported no difference in ADG cattle grazing pearl millet from August through October, and sorghumsudangrass in August and September, reporting about $0.45 \mathrm{~kg} \mathrm{hd}^{-1} \mathrm{~d}^{-1}$ for a 2-year study. Hill et al. [9] also reported no difference, due to pearl millet cultivar, in the nutritive value or ADG of $231 \mathrm{~kg}$ beef heifers $\left(0.67 \mathrm{~kg} \mathrm{hd}^{-1} \mathrm{~d}^{-1}\right)$. Parish et al. [20] reported the same for sudangrass cultivars, measuring $0.82 \mathrm{~kg} \mathrm{hd}^{-1} \mathrm{~d}^{-1}$ for beef steers, and heifers of similar weight to those used by Hill et al. [9]. Parish et al. [20] measured reduced ADG after $28 \mathrm{~d}$ of grazing, attributing it to increased fiber due to plant maturity when plants grew from about 42 to 98 DAP. In the present study, grazing was initiated about 48 and 86 DAP in 2013 and 2014, respectively, and, as mentioned, the pearl millet forage was more mature in 2014.

The year-forage effect was not significant for any component of live-weight gain ha ${ }^{-1}$ (Table 3). Pre-frost gains did not differ between pearl millet and sorghum-sudangrass, indicating similar animal weight gain during that period. While animals were removed from sorghum-sudangrass immediately pre-frost, requiring an alternative pasture [10], animals continued grazing pearl millet to gain an additional $95 \mathrm{~kg} \mathrm{ha}^{-1}$, leading to greater total gain ha ${ }^{-1}$ compared to sorghum-sudangrass (Table 3 )

In 2013, grazing was initiated barely 1.5 months after planting. Grazing would have kept both forages more finely stemmed and leafier than in 2014 when grazing was initiated 2.5 months after planting and both pasture types were much more mature. This being stated, Kidambi et al. [22] reported that cattle grazing sorghum forage consume mostly leaves and avoid stems, and Fontaneli et al. [5] found greater nutritive value in leaves than stems. Thus, selective grazing of the leaves even later in the season could provide for sustained gains in grazing systems compared to stored feeds that include the whole plant. In 2014, the nutritive value of whole plant pearl millet was more influenced by the later maturity (Table 2) and, thus, individual animal weight gain, as measured by ADG, was 
reduced to the level of sorghum-sudangrass (Table 4). Hence, in each year the increased total gain was more related to the longer grazing period on pearl millet, permitted by the fact that it does not produce HCN when frosted [13].

\section{Conclusions}

Both sorghum-sudangrass and pearl millet are well adapted to semiarid regions when irrigated and have value for late-summer pastures, providing equal dry matter yield for grazing. At the same level of nutritive value, pearl millet provided greater average daily gains than sorghum-sudangrass and sustained equal gains at lesser nutritive value. This suggests that pearl millet has beneficial nutritive value qualities not indicated by the analyses used, and that allow it to be more forgiving in regard to the nutritive value effects of forage maturity on animal weight gain. Pearl millet allows for extended grazing of available forage throughout the unpredictable frost-prone autumn period when livestock must be removed from sorghum forages, due to the production of potentially toxic levels of $\mathrm{HCN}$. This factor alone affords producers an opportunity to increase returns on the similar investment each year of establishing and managing warm-season annual forage crops for autumn grazing, as well as allowing for either greater forage accumulation by cool-season perennial or annual species for winter through early spring grazing or a reduction in hay feeding costs.

Author Contributions: Conceptualization, L.M.L. and E.J.S.; methodology, L.M.L. and E.J.S.; validation, L.M.L. and E.J.S.; formal analysis, L.M.L. and E.J.S.; investigation, L.M.L., L.H.S., S.H.C., and E.J.S.; resources, L.M.L., S.H.C., and E.J.S.; data curation, L.M.L. and E.J.S.; writing-original draft preparation, L.M.L. and E.J.S.; writing—review and editing, L.M.L., L.H.S., S.H.C., and E.J.S.; supervision, L.M.L. and E.J.S.; project administration, L.M.L. and E.J.S. All authors have read and agreed to the published version of the manuscript.

Funding: Salaries and research support were provided by state and federal funds appropriated to the New Mexico Agricultural Experiment Station. This research was also partially supported by Hatch Projects NM-LAURIAULT-10H (accession 0221381), NM-LAURIAULT-14H (accession 1004803), and NM-LAURIAULT-19H (accession 1021538); and the NMSU Corona Range and Livestock Research Center who provided the cattle and funding for freight.

Institutional Review Board Statement: All animal handling and experimental procedures were in accordance with guidelines set by the New Mexico State University Institutional Animal Care and Use Committee (Approval codes 2010-002 and 2014-034).

Informed Consent Statement: Not applicable.

Data Availability Statement: Data are available upon reasonable request from the authors.

Acknowledgments: The authors gratefully acknowledge technical and field assistance by Jason Box, Jared Jennings, Shane Jennings, and Hubert Roberts and secretarial assistance by Patty Cooksey, all at Tucumcari; and the staffs with the NMSU Library Document Delivery Service; NMSU College of Agricultural, Consumer and Environmental Sciences Information Technology; and other University support services.

Conflicts of Interest: The authors declare that no conflict of interest is associated with this research.

\section{References}

1. Assis, R.L.; Freitas, R.S.; Mason, S.C. Pearl millet production practices in Brazil: A review. Exp. Agric. 2018, 54, 699-718. [CrossRef]

2. Machicek, J.A.; Blaser, B.C.; Darapuneni, M.; Rhoades, M.B. Harvesting regimes affect brown midrib sorghum-sudangrass and brown midrib pearl millet forage production and quality. Agronomy 2019, 9, 416. [CrossRef]

3. Kirksey, R.E.; Lauriault, L.M.; Cooksey, P.L. Weather Observations at the Agricultural Science Center at Tucumcari-1905-2002; Res. Rep. 751; New Mexico State University Agricultural Experiment Station: Las Cruces, NM, USA, 2003; Available online: https: / / cahe.nmsu.edu/pubs/research/weather_climate/RR751.pdf (accessed on 8 September 2020).

4. Hanna, W.W.; Torres-Cardona, S. Pennisetums and Sorghums in an Integrated Feeding System in the Tropics. In Tropical Forage Plants: Development and Use; Pitman, W.D., Sotomayor-Rios, A., Eds.; CRC Press: Boca Raton, FL USA, 2001; pp. 193-200. [CrossRef] 
5. Fontaneli, R.S.; Sollenberger, L.E.; Staples, C.R. Yield, yield distribution, and nutritive value of intensively managed warm-season annual grasses. Agron. J. 2001, 93, 1257-1262. [CrossRef]

6. Gleadow, R.M.; Ottman, M.J.; Kimball, B.A.; Wall, G.W.; Pinter, P.J., Jr.; LaMorte, R.L.; Leavitt, S.W. Drought-induced changes in nitrogen partitioning between cyanide and nitrate in leaves and stems of sorghum grown at elevated $\mathrm{CO}_{2}$ are age dependent. Field Crops Res. 2016, 185, 97-102. [CrossRef]

7. Redmon, L.A.; Rouquette, F.M., Jr.; Florence, M.J. Use of mefluidide to alter growth and nutritive value of pearl millet. J. Plant Nutr. 2003, 26, 279-296. [CrossRef]

8. Ward, J.D.; Redfearn, D.D.; McCormick, M.E.; Cuomo, G.J. Chemical composition, ensiling characteristics, and apparent digestibility of summer annual forages in a subtropical double-cropping system with annual ryegrass. J. Dairy Sci. 2001, 84, 177-182. [CrossRef]

9. Hill, G.M.; Hanna, W.W.; Gates, R.N. Pearl millet cultivar and seeding method effects on forage quality and performance of grazing heifers. J. Prod. Agric. 1999, 12, 578-580. [CrossRef]

10. Barnhart, S.K. Fall Frost Effects of Forage; Integrated Crop Management News; Iowa State University Extension and Outreach: Ames, IA, USA, 2008; Available online: https: / / crops.extension.iastate.edu/cropnews / 2008/10/ fall-frost-effects-forage (accessed on 27 August 2020).

11. Coleman, S.W.; Rao, S.C.; Volesky, J.D.; Phillips, W.A. Growth and nutritive value of perennial $C_{3}$ grasses in the Southern Great Plains. Crop Sci. 2010, 50, 1070-1078. [CrossRef]

12. Rabas, D.L.; Schmid, A.R.; Martin, G.C. Relationship between chemical composition and morphological characteristics in sudangrass and sorghum $X$ sudangrass hybrids. Agron. J. 1970, 62, 762-763. [CrossRef]

13. Upadhyaya, H.D.; Reddy, K.N.; Pattanashetti, S.K.; Kumar, V.; Ramachandran, S. Identification of promising sources of fodder traits in the world collection of pearl millet at the ICRISAT genebank. Plant Gen. Resourc. Characteriz. Utiliz. 2018, 16, 127-136. [CrossRef]

14. NMED. NMED Groundwater Quality Bureau Guidance: Above Ground Use of Reclaimed Domestic Wastewater; New Mexico Environment Department: Santa Fe, NM, USA, 2007. Available online: https:/ / cloud.env.nm.gov /water/?r=5582\&k=cdcde6cbdf (accessed on 26 May 2021).

15. SAS Institute. The SAS 9.3 for Windows; SAS Institute Inc.: Cary, NC, USA, 2013.

16. Littell, R.C.; Milliken, G.A.; Stroup, W.W.; Wolfinger, R.D. SAS System for Mixed Models; SAS Institute: Cary, NC USA, 1996; 656p, ISBN 13 978-1555447793.

17. Saxton, A.M. A macro for converting mean separation output to letter groupings in Proc Mixed. In Proceedings of the 23rd SAS Users Group International, Nashville, TN, USA, 22-25 March 1998; Lex, J., Ed.; SAS Institute: Cary, NC, USA, 1998 ; pp. $1243-1246$.

18. Franzluebbers, A.J.; Stuedemann, J.A. Crop and cattle responses to tillage systems for integrated crop-livestock production in the Southern Piedmont, USA. Renew. Agric. Food Syst. 2007, 22, 168-180. [CrossRef]

19. Fulkerson, W.J.; Hordagoda, A.; Neal, J.S.; Barchia, I.; Nandra, K.S. Nutritive value for forage species grown in the warm temperate climate of Australia for dairy cows: Herbs and grain crops. Livest. Sci. 2008, 114, 75-83. [CrossRef]

20. Parish, J.A.; Parish, J.R.; Best, T.F. Assessment of 3 sudangrass cultivars for summer stocking of beef steers. Prof. Anim. Sci. 2013, 29, 395-402. [CrossRef]

21. Vendramini, J.M.B.; Sollenberger, L.E.; Lamb, G.C.; Foster, J.L.; Liu, K.; Maddox, M.K. Forage accumulation, nutritive value, and persistence of 'Mulato II' brachariagrass in northern Florida. Crop Sci. 2012, 52, 914-922. [CrossRef]

22. Kidambi, S.P.; Matches, A.G.; Karnezos, T.P.; Keeling, J.W. Mineral concentrations in forage sorghum grown under two harvest management systems. Agron. J. 1993, 85, 826-833. [CrossRef] 